Research, part of a Special Feature on Strengthening adaptive capacity

\title{
History and Local Management of a Biodiversity-Rich, Urban Cultural Landscape
}

\author{
$\underline{\text { Stephan Barthel }}^{1}, \underline{\text { Johan Colding }}^{2}, \underline{\text { Thomas Elmqvist }}^{1}$, and $\underline{\text { Carl Folke }}^{1}$
}

\begin{abstract}
Urban green spaces provide socially valuable ecosystem services. Through an historical analysis of the development of the National Urban Park (NUP) of Stockholm, we illustrate how the coevolutionary process of humans and nature has resulted in the high level of biological diversity and associated recreational services found in the park. The ecological values of the area are generated in the cultural landscape. External pressures resulting in urban sprawl in the Stockholm metropolitan region increasingly challenge the capacity of the NUP to continue to generate valuable ecosystem services. Setting aside protected areas, without accounting for the role of human stewardship of the cultural landscape, will most likely fail. In a social inventory of the area, we identify 69 local user and interest groups currently involved in the NUP area. Of these, 25 are local stewardship associations that have a direct role in managing habitats within the park that sustain such services as recreational landscapes, seed dispersal, and pollination. We propose that incentives should be created to widen the current biodiversity management paradigm, and actively engage local stewardship associations in adaptive co-management processes of the park and surrounding green spaces.
\end{abstract}

Key Words: ecosystem services; local management; Nationalstadsparken; resilience; social-ecological system; Stockholm Urban Park; urban ecology

\section{INTRODUCTION}

Urban ecological systems have been described as profoundly different from non-urban systems, with some of the most diverse ecological conditions on the planet (Collins et al. 2000, Grimm et al. 2000). Urban green spaces are highly patchy and dynamic, formed by biophysical and ecological drivers on the one hand, and social and economic drivers on the other (Pickett et al. 2001). Given the accelerating rate of urbanization worldwide, urban green spaces are becoming increasingly important to society as nodes of interactions between humans and nature. Urban green spaces generate a diverse set of ecosystem services of substantial significance for human well-being (Bolund and Hunhammar 1999). Their dynamics are shaped by human activities in what we refer to as a coupled social-ecological system (Berkes and Folke 1998).

Many green spaces in cities that have become disconnected from the wider environment tend to lose biodiversity and erode (Recher and Serventy 1991, Drayton and Primack 1996). Hence, protecting green spaces in isolation will often fail to sustain the capacity of urban ecosystems to generate services. Revitalization and broadening of the current management system from conservation in legally protected areas to stewardship of the urban landscape is a direction put forward in Swedish policy (Swedish Government 2002). It involves bringing nature management closer to the citizenry and acknowledging the diversity of user and interest groups that have a stake in management.

In this paper, we analyze the emergence of a larger urban green space, a cultural landscape currently known as the National Urban Park (NUP) of Stockholm (Elmqvist et al. 2004) (Figs. 1 and 2). In an historical account, we describe how the area has been transformed and governed by human actions and cultural influences, beginning with a low human-impact period, and currently facing a period 
of high urbanization pressure that, in 1995, resulted in legislative protection for the park. Most likley, an integrated management approach that incorporates surrounding land uses and green wedges will be required for the NUP (Colding et al., in preparation) (Fig. 1).

We also identify, by means of a social inventory, the main groups of actors in the NUP (Schultz et al. 2004). When conducting ecological research in urban areas, a social inventory is crucial because it provides clues on how to design and stimulate the development of more effective biodiversity management systems. In this context, we emphasize the existence of numerous local stewards and local stewardship associations involved in the management of the NUP. Such stewards include individuals and groups of people involved in the management of natural resources, habitat, and ecosystems. They tend to operate at a local scale, often below the municipality level, and their engagement may be voluntary, with an interest in stewardship. They are often socially connected in networks across vertical and horizontal levels (Olsson et al. 2004). In our view, such local groups represent an undervalued, sometimes not even recognized, source of experience in ecosystem management and governance. Finally, we discuss how their integration in adaptive co-management systems may provide more efficient management of biodiversity and ecosystem services in the NUP.

This paper is part of the Swedish contribution to the Millennium Ecosystem Assessment (MA) ( Www.millenniumassessment.org/), and part of the research of the Stockholm Urban Assessment (SUA-Sweden) (

www.ctm.su.se/SummaryofStockholmUr/). The objectives of SUA-Sweden are to investigate how adaptive capacity can be built to better respond to social-ecological change, and more specifically, to find effective ways to manage urban ecosystem services. The aim is to provide knowledge for designing governance systems that better take into account social and ecological dynamics and critical scales in biodiversity management for the wellbeing of the urban population of Stockholm (Colding et al. 2003, Elmqvist et al. 2004).

The paper begins with a description of the study area (Fig. 2), followed by information on the methods used for the historical account and the social inventory. We then describe the historical development of the NUP, showing how influential drivers, such as property rights, changes in human perceptions of nature, the industrial revolution, and urban population growth, have contributed to the formation of its various ecosystems and its current rich biodiversity. In the next section, we present an inventory of key local stewards and associations that operate the various sites (biotopes/habitats) in the park, and analyze their bundles of rights to resources in relation to the ecosystem services of the area. Based on this information, we discuss management implications for co-evolved, social-ecological systems in an urban context.

\section{STUDY AREA}

Stockholm County has one of the largest population concentrations in Scandinavia, with about 1.8 million people. The city of Stockholm, the capital of Sweden, has 750000 residents ( www.ab.lst.se, see Elmqvist et al. 2004). The case studies of SUASweden focus on the greater metropolitan area of Stockholm County, with special attention given to the NUP and its surrounding green space. This green space is connected to the larger green structure by one of ten green wedges that extend from the rural parts of the County toward the center of Stockholm (see Fig. 1).

Figure 1 shows the location of the NUP, the focal point of this paper. The NUP is located next to the inner city of Stockholm, situated between Lake Mälaren and the Baltic Sea. The park covers 2643 ha, of which 813 ha is open water, and forms the largest green space structure in the northern and eastern parts of Stockholm (Löfvenhaft 2002b). Three municipalities share the land, and the park borders four other municipalities. The park extends from the landward end of the Stockholm archipelago, via Djurgården and Haga-Brunnsviken, to the grounds of Ulriksdal Palace to the northwest (see Fig. 2). The large populations of oak (Quercus robur and $Q$. petrea) make the park unique from an international perspective. Also, few areas of equivalent size in Sweden show such a high biodiversity as the NUP (Löfvenhaft 2002b, Bråvander and Jakobsson 2003).

Since 1995, the park has been governed by a specific law under the Swedish Environmental Code as an area of national interest. The area is the first National Urban Park in the world. It owes its legal protection to various pressure groups, and can be viewed as a response to local concerns about loss of green space. 
Fig. 1. Overview of the green space structure in Stockholm and the location of the National Urban Park

\section{Stockholm overview, green wedges and the National Urban Park (NUP)}

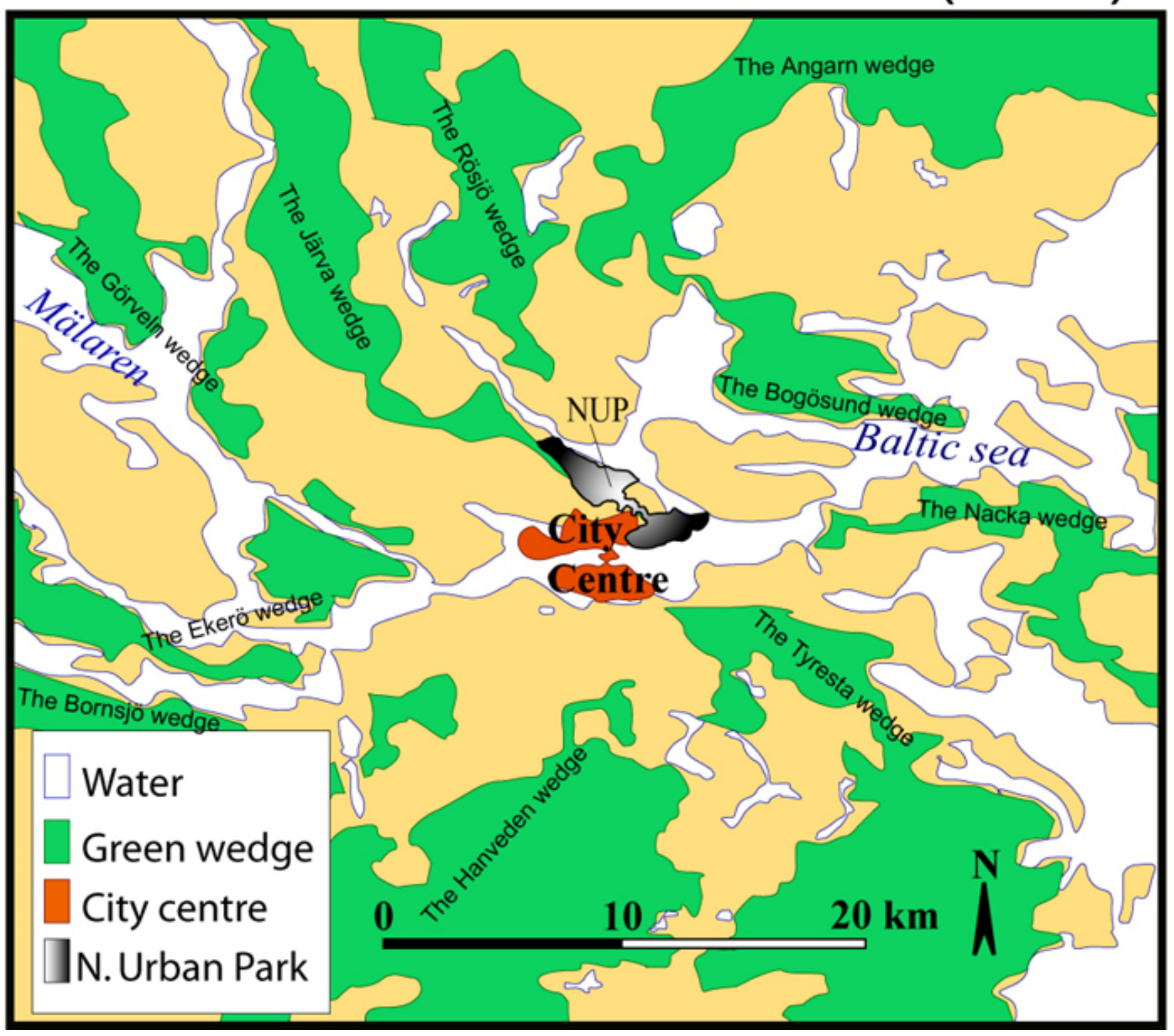


Fig. 2. The National Urban Park

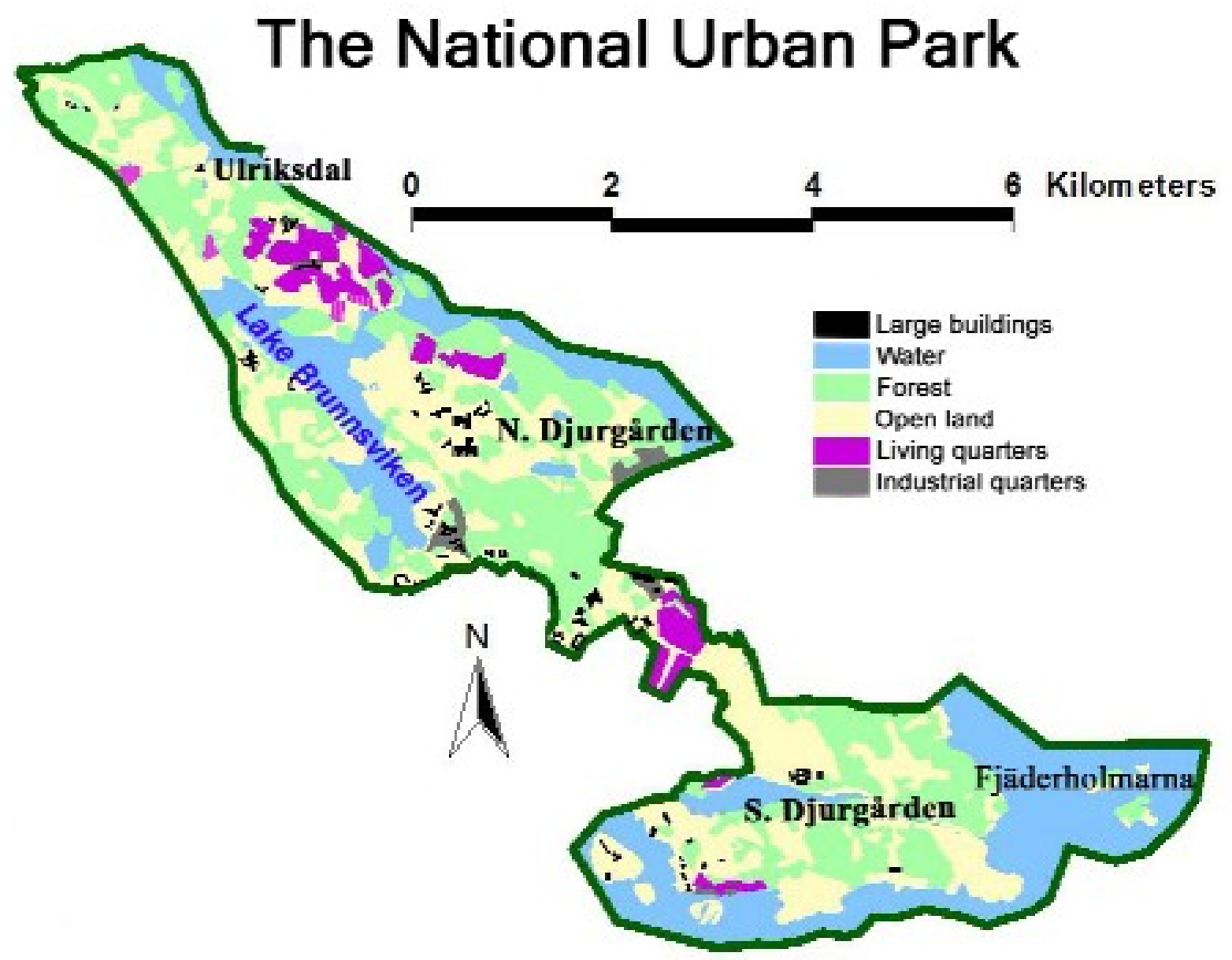

The law stipulates that new buildings and new facilities within the area may be developed and other measures taken only if they can be done without intruding on the park's landscape or natural environment, and without causing harm to the landscape's natural and cultural values (Rubenson 2000). However, despite legal protection, urban sprawl has not been halted on the park's fringe areas. Aside from its biological value, the park has unique historical and cultural values. It is estimated that the NUP attracts 15 million visitors each year, many of whom visit the park for recreational purposes (Stockholm Planning Administration 1997).

Water characterizes much of the rift valley landscape of the NUP. A number of islets, especially
Fjäderholmarna, have a rich flora and bird life typical of the archipelago. Djurgården, on the shoreline of the Baltic Sea, has lush vegetation and landscape characteristics typical of the Stockholm archipelago: low-elevation, pastoral meadows and bedrock populated with scattered Scots pine (Pinus sylvestris). There are also a number of wetlands and small water bodies. The royal heritage of the NUP can be seen in the vast lawns, scattered broadleaf trees, alleys, forested hills, and dense forests. In addition, there are culturally shaped pastures with rich ground flora, and bedrock outcrops with dry land flora (Stockholm County Administration Board 1999). There are three royal castles in the park: Rosendal, Haga, and Ulriksdal. English-style landscape parks characterize the landscape around 
Lake Brunnsviken, with lookouts over the lake and $15^{\text {th }}$ century buildings with large lawns. The renaissance-style park typifies the locale around Ulriksdal, located on the coast (see Fig. 2).

Urban gardens are another element that characterizes the park. A botanical garden, Bergianska, is situated along the shoreline of Lake Brunnsviken. It contains 32 ha of gardens and different forest biotopes, including about 9000 species of plants (Edlund 1991, Lundevall 1997). Another popular example is the garden at Rosendal, which focuses on organic horticulture ( http://www.rosendalstradgard.com/).

In addition, there are six allotment gardens in the park, a number of recreational establishments (such as an amusement park and a theatre), several museums, and several scientific and educational establishments, as well as permanent residential houses, and even whole city quarters with large apartment buildings. Löfvenhaft and Lannek (2002) have classified up to 24 different biotopes within the NUP (see Table 1). For a complete description of urban green spaces in the Stockholm metropolitan area, see Colding et al. (in preparation).

\section{METHODS}

The study of human influences on urban ecosystems stresses the importance of analyzing interacting social dynamics as well (Kinzig 2001, Berkes et al. 2003, Olsson et al. 2004). In this paper, analyses of social dynamics that affect contemporary ecosystem dynamics in the park include 1) an historical survey of past land uses and management of the park, 2) a social inventory (Schultz et al. 2004) of stewardship groups that are currently active in the park, and 3) a qualitative assessment of ecosystem services linked to these stewardship groups.

The methods employed for describing the historical development of the park include a study of the literature and of relevant maps, and information derived from the Internet. The NUP of Stockholm is a rather well-documented area (e.g., Edlund 1991, Brusewitz and Ekman 1995, Fogelfors and Hansson 1997, Lundevall 1997, Stockholm Planning Administration 1997, Stockholm County Administration
Table 1. Number of different types of biotopes found within the National Urban Park

\section{Biotopes in the National Urban Park}

1 Developed land with sparse vegetation cover $(0$ $30 \%$ )

2 Developed land with dense vegetation cover (30$50 \%$ )

3 Dense broadleaved deciduous forest

4 Sparse broadleaved deciduous forest

5 Deciduous forest

$6 \quad$ Mixed forest

$7 \quad$ Coniferous forest

8 Bedrock with scattered Scots pine

9 Moist grassland with trees and shrubs

10 Mesic grassland with broadleaved deciduous trees or other vegetation

11 Dry grassland with broadleaved deciduous trees or other vegetation

12 Bedrock with broadleaved deciduous trees or other vegetation

13 Moist grassland

14 Mesic grassland

15 Dry grassland

16 Arable field or allotment

17 Bedrock outcrops

18 Remaining bare ground

19 Wetland with sparse vegetation

20 Wetland with dense vegetation

21 Wet deciduous forest

22 Open water with floating vegetation

23 Floating water vegetation

24 Grassy shallow water

Source: Löfvenhaft and Lannek 2002 
Board 1999, Lange 2000, Herdin 2002, Norrby 2002, Holm and Schantz 2002, Wirén 2002, Löfvenhaft 2002b, Andersson 2003, Borgström 2003). A number of maps of the area have been analyzed. Although some of these maps are over 300 years old (

http://www.djurgardskartor.lantmateriet.se/), we have mainly used recently produced biotope maps, such as the work by the Stockholm Planning Administration (1998), and Löfvenhaft and Lannek (2002).

The social inventory of the NUP was carried out in 2003. The results from the social inventory described in this paper focus on stewards dealing with green space management and user groups in the NUP, as well as the various user and property rights held by them. Thus, the paper presents information on social factors that influence the management dynamics of the NUP. Multiple forms of qualitative data (Patton 1980, Fowler 1993, Bernard 1994, Kvale 1996) were used to identify the park's user groups and stewardship groups, including internet searches, telephone surveys, field and participatory observations, map analyses, and a literature review (Appendix 1 provides details on the websites and maps consulted during this research, and on the interviews conducted with stakeholders). Semi-structured interviews were carried out between March and May 2003, and the interviews each lasted for about 1 hour. The interviewees were active when the park received its legal protection and have inside knowledge of locally evolved interest organizations in the park. They are also active in the network organization Alliance of the Ecopark (

http://www.ekoparken.org/). A telephone survey was conducted in 2003, with 69 identified organizations in order to obtain further information on whether they were active in management or not, where in the landscape they were active, and what kind of property rights they held (see Appendix 2, Table 2). All 69 organizations responded.

Following this, a qualitative attempt was made to assess ecosystem services provided by sites, as managed by stewardship groups. We estimated that these managed sites hold specific ecological processes and habitats for various compositions of species. We focused on the landscape scale in this inventory, and more specifically, on the heterogeneity of the landscape and ecosystem services provided by biotopes on a landscape level. Criteria were synthesized from the literature for connecting various types of urban green space or biotopes with characteristic ecosystem services (Folke et al. 1996, Baskin 1997, Costanza et al. 1997, Daily 1997, Daily et al. 1997, Nabhan and Buchmann 1997, Naylor and Ehrlich 1997, Niemi et al. 1998, Bolund and Hunhammar 1999, and Löfvenhaft 2002a). The link between ecosystem services and actor groups was made using these criteria (see Table 3 ) when analyzing various types of sites, as managed by the stewardship groups. Four characteric ecosystem services per site were chosen, in order to highlight that the various sites differ in the services they offer to the urban landscape, and some sites may, to varying degrees, support other ecosystem services as well.

\section{THE SOCIAL-ECOLOGICAL HISTORY OF THE NATIONAL URBAN PARK}

In this section, we analyze the social-ecological coevolution of the biodiversity-rich landscape of the NUP of Stockholm. To best present the history of this development, we have divided it into five periods, representing what we find to be major transformations in the relationship between the inhabitants and the environment: the agricultural period; the royal hunting period; the forestry and recreational period; the industrial period; and the urban sprawl period (see Fig. 3).

\section{The Agricultural Period}

The NUP is located in an area of Sweden where the landmass has risen above sea level by about $5 \mathrm{~mm}$ a year since the latest ice age (Loberg 1993). During the Bronze Age, the shoreline was about 14-20 m above the present-day shoreline. As soon as the first islands rose above sea level, they attracted hunter and gatherer societies, as is revealed by artifacts found in Bronze Age graves. Later, during the early Viking era, enough fine sedimentary soil was exposed to permit people to settle in villages and create an agricultural landscape (Lundevall 1997, cf. Bratt and Stockholms Läns Museum 1998). At that time, the shoreline was about $5 \mathrm{~m}$ higher than presently. Thus, there has never been a pre-human period in the current NUP area. The landscape was shaped by human action ever since land uplift processes provided suitable habitat for settlers (Gustavsson 1998). 
Table 2. Potential ecosystem services generated by urban green space of the NUP, and the number of local stewardship associations involved in managing and sustaining them

\begin{tabular}{lll}
\hline \hline $\begin{array}{l}\text { Potential urban ecosystem } \\
\text { services }\end{array}$ & $\begin{array}{l}\text { Criteria for green space and biotopes, } \\
\text { delivering each ecosystem service }\end{array}$ & $\begin{array}{l}\text { Number of stewards with different property } \\
\text { rights that affect each ecosystem service }\end{array}$ \\
\hline
\end{tabular}

\begin{tabular}{|c|c|c|c|c|}
\hline & & Owners & Proprietors & Claimants \\
\hline \multicolumn{5}{|l|}{ Experiential services } \\
\hline Recreation/cultural values & $\begin{array}{l}\text { Green space in NUP open to and enjoyed } \\
\text { by the public }\end{array}$ & 4 & 7 & 5 \\
\hline \multicolumn{5}{|l|}{ Regulating services } \\
\hline Noise reduction & $\begin{array}{l}\text { Street trees, lawns or urban forests close to } \\
\text { noisy areas }\end{array}$ & 5 & 6 & 0 \\
\hline Insect pest regulation & Habitat for predators of pests & 1 & 8 & 1 \\
\hline Surface water drainage & Permeable surfaces like lawns, etc. & 3 & 2 & 0 \\
\hline Regulation of microclimate & $\begin{array}{l}\text { In city vegetation/street trees, vegetation } \\
\text { close to buildings, and water bodies }\end{array}$ & 3 & 2 & 0 \\
\hline Air filtration & $\begin{array}{l}\text { Street trees, lawns or urban forests close to } \\
\text { sources of pollution }\end{array}$ & 5 & 0 & 0 \\
\hline Nutrient retention & Wetlands & 0 & 2 & 2 \\
\hline \multicolumn{5}{|l|}{ Supporting services } \\
\hline Seed dispersal & $\begin{array}{l}\text { Important feeding areas and habitats for } \\
\text { mobile links }\end{array}$ & 1 & 10 & 4 \\
\hline Pollination & Important feeding areas for pollinators & 0 & 11 & 2 \\
\hline Gene conservation & $\begin{array}{l}\text { Areas in NUP described as important } \\
\text { habitats for red-listed species }\end{array}$ & 2 & 4 & 5 \\
\hline
\end{tabular}

Since the Viking era, there have been numerous shifts in land use in the area that constitutes the contemporary NUP. The dominant land use during the first half of the second millennium was agriculture. The present-day land mosaic in the NUP consisting of open land areas and forests was established during the agricultural land-use era (see Fig. 4). Broadleaf stands, especially oak (Q. robur) trees, were favored (Stockholm County Administration Board 1999). In the Middle Ages, the primary landowners were monasteries and the church. The first regulations concerning oak as a natural resource were written during this period, in 1347, oak being valued then for its hardwood and its acorns (Herdin 2002). Between the $13^{\text {th }}$ and $15^{\text {th }}$ centuries, the monasteries increased their landholdings, but over time, members of the royalty became attracted to the area and slowly changed the land use. In 1452, the southern sector of an area called "Djurgården" (see Fig. 2) became royal property, and a century later the entire locale was at the disposal of the Swedish King Gustav Vasa (Stockholm Planning Administration 1997). This marked the beginning of a royal management tradition that, to some extent, continues today. Grazing was intensified after the royal takeover, affecting natural regeneration of broadleaved trees. The park's forests were estimated to be in poor condition by the end of the agricultural period (Herdin 2002). 
Table 3. Local stewardship associations involved in the management of the National Urban Park

Level of governance

\begin{tabular}{|c|c|c|c|c|c|c|}
\hline Stewards: Organizations and associations & $\begin{array}{l}\text { Nu- } \\
\text { mber }\end{array}$ & $\begin{array}{l}\text { Property } \\
\text { Right }\end{array}$ & Global & National & Regional & Local \\
\hline $\begin{array}{l}\text { World Wildlife Foundation (WWF); the Swedish } \\
\text { Society for Nature Conservation; Patrullen Utter; } \\
\text { Bergshamra för alla; Stockholms Ornitologiska } \\
\text { förening }\end{array}$ & 5 & Claimants & 1 & & 1 & 3 \\
\hline $\begin{array}{l}\text { Stockholm Water Inc.; Royal Djurgården Admin.; } \\
\text { Botanic Garden of Bergius; Garden of Rosendal; } \\
\text { the } 4 \text { H Farm of Stora skuggan; Allotment areas of } \\
\text { Söderbrunn, Kvarnvreten, Ulriksdal, Frescati, } \\
\text { Bergshamra, and Stora skuggan; Outdoor Museum } \\
\text { of Skansen; Cemetery of Ulriksdal }\end{array}$ & 13 & Proprietors & & & 1 & 12 \\
\hline $\begin{array}{l}\text { National Property Board; Swedish National Road } \\
\text { Administration; Vasakronan; Akademiska hus; } \\
\text { Municipalities of Stockholm, Solna, and Lidingö }\end{array}$ & 7 & Owners & & 7 & 0 & 0 \\
\hline
\end{tabular}

\section{The Royal Hunting Period}

Agriculture was the dominant land use in the area until the end of the 1600 s, when royal hunting became ever more fashionable. During this period, the ruling elite of Sweden was strongly tied to the Royal Court (Edlund 1991). Consequently, the nobility built their residences around Stockholm and in the region around Lake Mälaren, called "Mälardalen."

In contrast to farmers of that time, who eradicated oak seedlings from their properties, oak populations found a refuge on the nobility's country estates, mainly because the demand for oak wood for shipbuilding material for the Crown's navy (Fogelfors and Hansson 1997). The contemporary NUP's oak population, which includes trees that are several hundred years old, forms part of the population in the Mälardalen landscape, and is one of the major oak populations of northern Europe (Herdin 2002).

The predominant view of nature during the $1600 \mathrm{~s}$ was that it should be pruned and controlled, to symbolize power and status (Frängsmyr 1984, Edlund 1991). The ideal was the royal park at
Versailles, with its mathematical formations and details influenced by antiquity. During this period, in the mid 1600 s, a castle with a renaissance park was built in the "Ulriksdal" area (see Fig. 4). The castle was later transformed into a royal palace (Edlund 1991, Schantz 2002). In the 1690s, a large part of Djurgården was transformed into a royal hunting ground that was enclosed by a $20-\mathrm{km}$ wooden fence to protect the royal game from predators and poachers (Brusewitz and Ekman 1995). Grazing inside the fence was intensive, partly because of the large numbers of deer and partly because of grazing livestock owned by farmers, who could pay an entrance fee (Lundevall 1997). In 1729 , the number of deer was estimated to be more than 1500, resulting in even more intensive grazing pressure than that experienced during the agricultural period. In addition, theft of wood was common. Wood for heating was highly valued by the citizens during cold winters, because almost all the local forests had been harvested to produce charcoal for the ironworks (Stockholm Planning Administration 1997). All this culminated in the deforestation of the park (Lundh 1928), although the situation was estimated to be better inside the fence than outside due to the royal protection (Stockholm County Administration Board 1999). A 
Fig. 3. Summary of key events shaping the relationship between the residents of Stockholm and the environment.

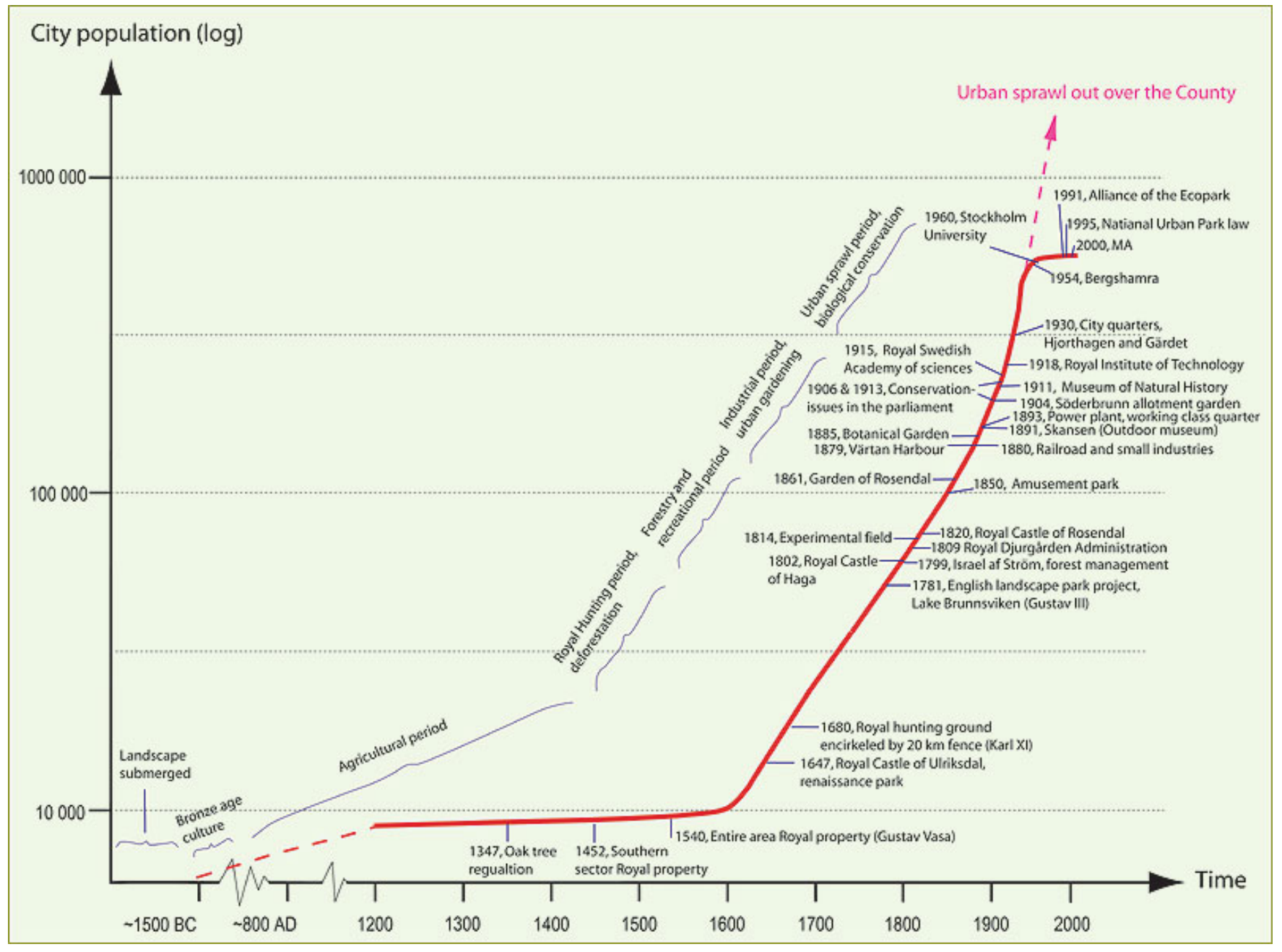

royal management agency, the Royal Djurgården Administration (in Swedish, "Kungliga Djurgårdsförvaltningen" (KDF);

http://www.djurgardskartor.lantmateriet.se/), was established around 1809 to manage the hunting ground (Stockholm County Administration Board 1999), and it is still one of the main managers of the park ( http://www.djurgardskartor.lantmateriet.se/ ).

\section{The Forestry and Recreational Period}

There seem to have been two separate events that triggered a response to counteract deforestation. First, there was a conceptual change in the humannature relationship during the 1700s, and second, the birth of modern forestry in Sweden occurred at the end the $18^{\text {th }}$ century.

The change in the human-nature relationship was inspired by the English landscape park concept (cf. Johanisson 1984, cf. Edlund 1991, cf. Schantz 2002). The concept was based on romantic ideals, with a worldview of nature as divine. The landscape 
Fig. 4. Geographical overview.

\section{Geographical overview, the location of the National Urban Park}

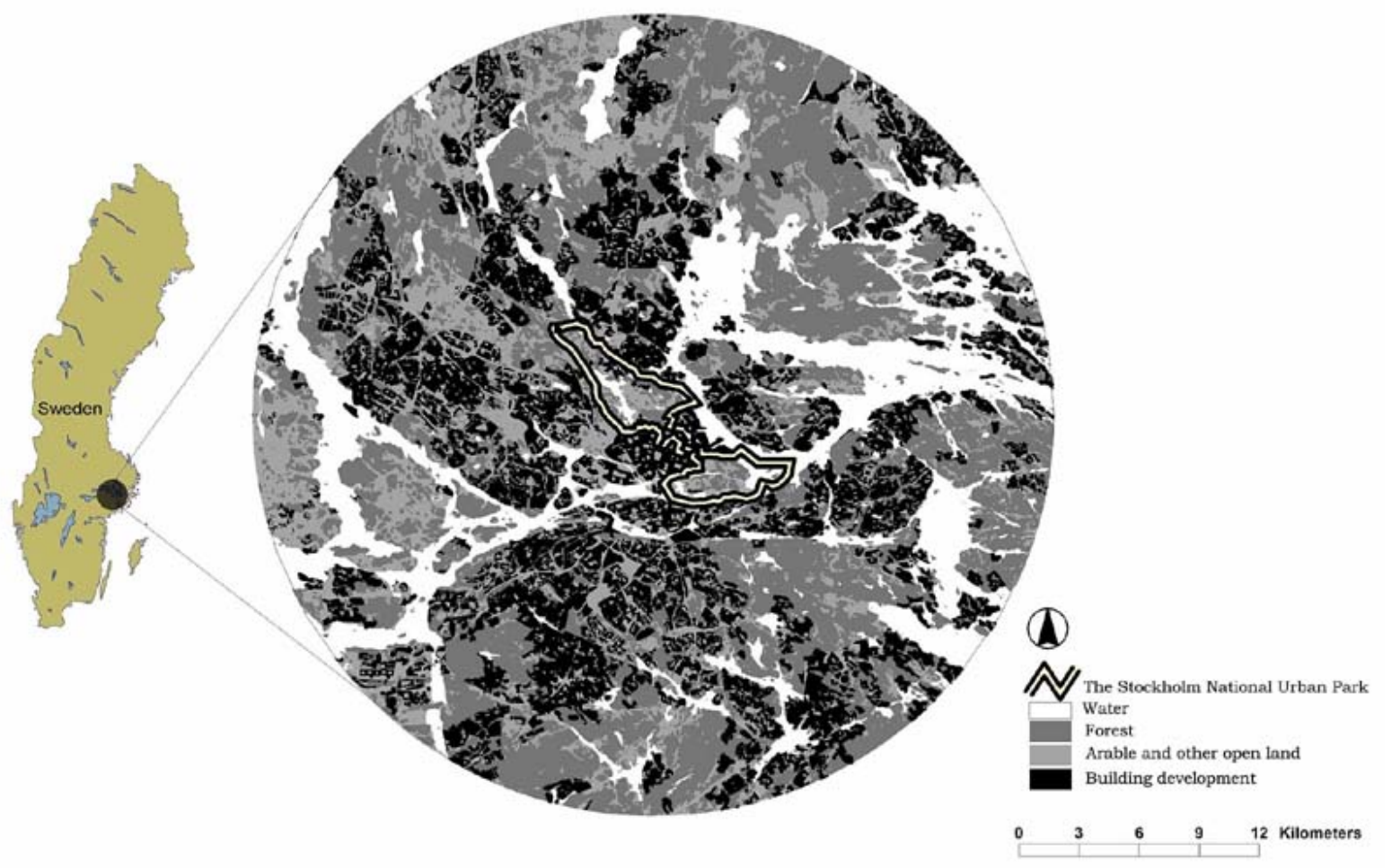

management objective during this time was to enhance the scenic beauty of the natural landscape, and not to prune nature as prescribed by the French ideal. With these ideals in mind, King Gustav III initiated a large English landscape park project around Lake Brunnsviken in 1781 (see Fig. 2).

Twenty years later, Israel af Ström became the chief forest officer of Djurgården. He perceived the forests of the park to be in a terrible state, and he was determined to radically enhance their condition (Lundh 1928). In the first half of the 1800s, af Ström established a forest institute for the dissemination of his ideas and nurseries that would generate trees for various planting projects. He also created what are thought to be the first written forest management plans in Sweden (Slottsarkivet E1:5 1807), and he was particularly interested in oak, because of the high demand for it from shipbuilders (Herdin 2002). Israel af Ström's efforts received unexpected support as the project coincided with Sweden's installation of a French army marshal as King of Sweden. Jean-Baptiste Bernadotte became Karl XIV Johan and ruled Sweden from 1818 to 1844 (Lundevall 1997). The new King was fascinated by the landscape of the NUP and wanted it to resemble a continental landscape. At his initiative, a channel was constructed, and he built his summer residence, called "Rosendals slott" next to it (Lundevall 1997). The ideas of the new King and Israel af Ström shaped the area into a park-like landscape. Broadleaf and pine forests, alleys, and exotic tree species were 
planted over large parts of the formerly overgrazed area, giving the landscape much of its character today (Lange 2000).

Ordinary citizens had been fenced out of royal parks and gardens until the 1700s. The main social drivers that led to a shift toward public use of the green space in Stockholm were the sevenfold population growth that took place during the $17^{\text {th }}$ and $18^{\text {th }}$ centuries, and international movements, such as the English landscape park concept and the French Revolution of 1789 (van Rooijen 2004). At the end of the 1700s, there were about 70000 dwellers in a city that was notorious for its filth, stench, and disease ( http://www.historia.su.se/urbanhistory/, Edlund 1991, Nilsson 2000). During the 1800s, the park became the main recreational attraction for the residents. Recreational institutions such as, for example, an amusement park, a theatre, several museums, and an outdoor museum were established (Lundevall 1997). Up to 10000 people a day from all walks of society would visit the area to walk, ride, eat, and dance. This trend of opening up parks for public use occurred simultaneously in several central European cities (van Rooijen 2004).

\section{The Industrial Period}

The industrial revolution, initiated in the mid $1800 \mathrm{~s}$ in Stockholm, imposed major changes in society that, in turn, had a long impact on the NUP. For example, the main harbor of Stockholm was built there, along with a railroad and adjoining station buildings and manufacturing industries. A gasfueled power plant was also built, with its power lines cutting across the park (Lignell 1995). In addition, a working-class quarter was created-the forerunner of modern urban sprawl in the area, characterized by large-scale apartment building projects (Lundevall 1997).

One outcome of industrialization, probably in response to the process of migration from rural areas (cf. Nilsson 2000), was a demand for gardening. The Garden City, the Swedish allotment gardening movement, and the botanical gardens were created during this era. In 1814, the Royal Swedish Academy of Agriculture established an area for experimental agriculture in the park. Its purpose was to enhance agricultural production, according to the ideals of the industrial revolution. One hundred hectares were irrigated with ditches and turned into croplands, fruit orchards, and horticultural gardens that were used for agricultural experiments. The area was called the Experimental Field ("Experimentalfältet") (Lange 2000). Gardening grew steadily in the park, and in 1861, the Swedish garden association started cultivation at the "Rosendal" castle property. The garden association developed an immense variety of species of fruit trees, vegetables, and exotic plants, and educated 700 gardeners between 1862 and 1911 (

http://www.rosendalstradgard.com/). Additionally, in 1885, the Botanical Garden relocated from the growing city to the shoreline of Lake Brunnsviken. The land was converted to horticultural plantations, and various forest biotopes and a garden school were also established (Edlund 1991, Lundevall 1997).

At the turn of the $20^{\text {th }}$ century, the population in the city of Stockholm exceeded 300000 (

http://www.historia.su.se/urbanhistory/) and industrialization had led to poor living conditions for much of the lower classes. In Stockholm, the first allotment garden area was established in 1904 at Djurgården. Of particular importance in sparking the gardening movement in Sweden was the work of Anna Lindhagen, who became the first chairperson of the Association of Allotment Gardens in Stockholm, founded in 1906 primarily through her work. She was inspired by socialaesthetic ideas of the time and believed that humans could realize their full potential in an aesthetically attractive setting. In the 50-year period following the movement's establishment in the park, another five allotment areas were created, areas that are still actively used as allotments (Lindhagen 1916, Nolin 2003, http://www.koloni.org/pdf/01.pdf).

\section{The Urban Sprawl Period}

Urban sprawl, defined as suburban growth, ribbon development, scattered and leapfrog development (Couch and Karecha 2003), accelerated at the beginning of the $20^{\text {th }}$ century in Stockholm, and led to the destruction of green space in the park. For example, the King at that time (King Oskar II) gave away land to friends for private residences, or to construct hospitals, military establishments, and schools (Lundevall 1997).

Community response to urban sprawl in the NUP began as early as 1906 and 1913, when the issue was raised in the Swedish parliament, and total protection of all unexploited land in the NUP was called for (Brusewitz and Ekman 1995; Lundevall 
1997). However, this response was not particularly successful at stemming urban sprawl. Pressure increased as the population of Stockholm more than doubled during the first half of the century (see Fig. 4). Several major scientific centers were built between 1909-1918, such as the Museum of Natural History, the Royal Institute of Technology, the Royal Swedish Academy of Sciences, and later, Stockholm University (1960) (Edlund 1991, Norrby 2002). Moreover, increased demand for housing during the 1930-1970s resulted in the establishment of entire new city quarters, such as Hjorthagen, Gärdet, and Bergshamra. By the end of the 1970s, approximately one third of the surface area of the NUP was covered by pavement and buildings. Consequently, habitats that were formerly connected, now became fragmented (Lundevall 1997, Löfvenhaft 2002a). In the 1980s, plans for massive development that would destroy major historical and biological values in the park were made public. This time, society was ready to respond.

During the 1960s and 1970s, the public became more concerned about the environment, and a vital environmentalist movement was born (Lundqvist 1971, Boström 2001). Consequently, the development threats of the 1980s ignited a passionate response at all levels of the community. A network of informal associations comprising more than 175000 members actively campaigned to protect the park (Waldenström 1995). This community response finally culminated in the enactment of the National Urban Park law in 1995. The NUP now enjoys legal status as an area of national interest. However, it is still under continuous pressure, and it remains to be seen whether the law can stem the tide of urban sprawl (Holm and Schantz 2002). Figure 4 summarizes the social-ecological development of the NUP and the key events, or mental models, that transformed the relationship between the residents of Stockholm and the environment.

\section{BIOLOGICAL DIVERSITY-A RESULT OF THE CULTURAL LANDSCAPE}

The historical social-ecological development of the NUP has created a unique cultural landscape that is rich in terms of biodiversity. Few areas of equivalent size in Sweden show such a high species diversity. The NUP covers only about $1 \%$ of the region of Uppland, and is one of the most frequently visited green spaces in Sweden, yet it hosts approximately $75 \%$ of all the species recorded in Uppland (Lundevall 1997, Brusewitz 1995). More than 1000 Lepidopteran species documented, 1200 Coleopteran species, and 250 bird species have been observed here. There are more than 60 red-listed insect species, of which 29 are threatened and 27 are vulnerable. Among fungi, 32 species are red listed. As well, more than 20 species of red-listed vascular plants, mammals, amphibians, reptiles, and fish can be found in the park (Löfvenhaft 2002a, Bråvander and Jakobsson 2003).

We propose at least three reasons for the high species diversity found in the NUP, all of which relate to past activities in land use and management. The first is the long continuity of royal land ownership throughout times of change in the surrounding areas. For example, grasslands and broadleaved forests are threatened biotopes in the Swedish landscape (Fogelfors and Hansson 1997, Löfvenhaft 2002a); the forest of the former royal hunting ground may be the best preserved in this part of Sweden because it enjoyed royal protection dating back many centuries (Brusewitz 1995). Because the landscape was strongly tied to royal land ownership, formal institutions and strong cultural traditions dedicated to its preservation were established.

The second reason, and perhaps most important, pertains to the long tradition of management policies that, over the years, have intentionally favored oak. The NUP has one of the largest populations of giant oaks in Europe, many of which were planted (Herdin 2002). About $25 \%$ of all tree species in Djurgården are oak trees (Bråvander 2003, Borgström 2003), some of which are at least 500 years old (Stockholm County Administration Board 1999). The oak is a keystone species in this geographical setting, producing a unique set of niches for flora and fauna dependent on old hollow trees (Ranius et al. 2001), and hosting up to 1500 other species of fungi, lichens, insects, birds, and bats (Hultgren et al. 1997). Of all red-listed insects $80 \%$ are linked to old-growth oak trees and lime trees (Gothnier et al. 1999). The large populations of oak make the park unique from an international perspective.

The third reason for the large number of species present in the NUP is that it contains many diverse biotopes (cf. Gothnier et al. 1999, Löfvenhaft $2002 \mathrm{~b}$ ). The 24 biotopes in the park (see Table 1), 
including various kinds of forest biotopes, grasslands, and wetlands, give rise to a highly patchy landscape (Peters and Goslee 2000). The park's landscape contains habitat for species that may unintentionally be dispersed by Stockholm's residents (cf. Sjöberg 2002). A striking example is that some of the more charismatic nesting bird species in the NUP originated from ancestors that escaped from the park's outdoor museum (Brusewitz 1995).

The three reasons presented above all relate to human intervention or management (i.e., are confined to social dynamics, and more specifically, related to property rights, oak management, and land use). The long, royal tradition of management and conservation of oaks can, in this context, be seen as slowly changing social variables that have contributed to ecological resilience in the presentday landscape of the NUP (cf. Carpenter et al. 2001). In other words, the contemporary landscape and the current biodiversity status of the NUP seem to be the result of co-evolution, or self-organization through mutual training (Colding and Folke 1997) between people and nature (Costanza et al. 1997). Consequently, conservation of the rich levels of biodiversity still depends on human intervention.

\section{LOCAL STEWARDS AND STEWARDSHIP ASSOCIATIONS OF THE PARK}

Historical review reveals that, over time, new actors became involved in the management of the area that today constitutes the NUP of Stockholm. The old tradition of royal land and government still continues, but has been supplemented, over time, by a much more diverse management structure that involves allotment areas and several recreational activities.

The contemporary bylaw-protected park is currently under serious pressure from urban sprawl as the Stockholm metropolitan area continues to grow, which has mobilized local groups to organize into lobbying organizations to counteract this pressure. In the next section we describe the result of the social inventory of local steward associations and their role in ecosystem management within the park.

\section{Local Stewardship Associations, Property Rights, and Management of Ecosystem Services}

The Stockholm metropolitan area has witnessed a remarkable growth in stewardship and conservation groups that articulate strong values for different aspects of the NUP. Examples include sport clubs, allotment garden associations, and bird-watching clubs. Many are organized under the umbrella organization Alliance of the Ecopark (in Swedish "Förbundet för Ekoparken"), which consists of 50 volunteer associations comprising more than 175 000 members ( http://www.ekoparken.org/). It was founded in 1991 in response to threats of vast developmental exploitation of the park. In 1995, the Alliance played a key role in securing legal protection for the park (Waldenström 1995, Wirén 2002).

Our inventory of local groups closely linked to the NUP identified 69 groups (Table 3). In Table 4, they are classified according to operational property rights, in accordance with Ostrom and Schlager (1996). A property right defines actions that individuals can take in relation to other individuals (Ostrom and Schlager 1996). Five bundles of operational-level property rights have been identified by Ostrom and Schlager (1996), including the right of access to an area or to the resource base as an authorized entrant; the right of extraction in order to obtain resource units, as an authorized user; the right of management to regulate internal use patterns and transform the resource by making improvements, as a claimant; the right of exclusion in determining who will have an access right and how that right may be transferred, as a proprietor; and the right of alienation, determining the right to sell or lease property, as an owner. Thus, an owner possesses all five of the above rights in a resource management system, whereas an authorized entrant only holds one, i.e., the right of access.

As can be concluded from Table 4, there are 44 authorized users in the NUP with limited rights to enter the area and extract resource units in accordance with what is allowed by the owners and by Swedish law. Examples include the local historical association of Djurgården, the Haga Boating Club, the Friends of Haga Brunnsviken, and the Association of authorized guides of Stockholm. Furthermore, there are 25 stewardship associations that manage the various locales in the NUP (see Fig. 5 ). In theory, they all hold management rights in the 
Table 4. Property right regimes, bundle of rights, and level of governance among local stewardship associations active in the Park

\begin{tabular}{|c|c|c|c|c|c|c|}
\hline \multirow{2}{*}{$\begin{array}{l}\text { Property right } \\
\text { regime }\end{array}$} & \multirow[t]{2}{*}{ Bundle of rights } & \multirow[t]{2}{*}{ No. of associations } & \multicolumn{4}{|c|}{ Level of governance } \\
\hline & & & Global & National & Regional & Local \\
\hline Users & Access \& withdrawal & 44 & & 3 & 2 & 39 \\
\hline Claimants & +Management & 5 & 1 & & 1 & 3 \\
\hline Proprietors & +Exclusion & 13 & & & 1 & 12 \\
\hline Owners & + Alienation & 7 & & 7 & 0 & 0 \\
\hline
\end{tabular}

area. Five hold only the right of management, i.e., they may be considered as claimants. These five include the World Wildlife Fund (WWF), a conservation organization that is active in a wetland grazing project, and the Swedish Society for Nature Conservation, Stockholm County (SNF), which is active in haymaking projects, oak planting projects, and the restoration and management of water bodies.

Thirteen of the 25 stewardship associations hold the additional right of exclusion, and may be considered proprietors. The

Royal Djurgården Administration (KDF) is a key proprietor because it manages about $80 \%$ of the ecosystems within the NUP, including most of the oak population (Herdin 2002, Borgström 2003). In their current management plan, from 1992-1993, the main purpose of management is to secure the continuity of the natural and cultural environment, and within this framework, also to meet the recreational needs of visitors.

Another important proprietor is Stockholm Water Inc. ("Stockholm Vatten AB"), which manages the NUP's water courses, lakes, and wetlands. Its main objectives are to restore wetlands and decrease polluted inflow from urban surroundings (Stockholm Environmental and Health Administration 1994). Urban gardens and six allotment gardens within the NUP are classified as proprietors because they hold the right of exclusion.

Seven of the 25 associations also hold the additional right of alienation, i.e., may be considered owners.
The National Property Board ("Statens Fastighetsverk") owns most of the land in the NUP and is responsible for its long-term maintenance. It is also involved in some direct management activities, although the KDF manages most of their holdings. Other key landowners in the NUP are the municipalities of Stockholm and Solna. The municipality of Stockholm acts both as a land developer responsible for the land-use planning through the Stockholm City Planning Administration, and with park maintenance through the Real Estate and Traffic Administration. The municipality of Solna has a similar dual structure. These dual roles of the municipalities may increase their risk of conflict of interests in decision making and planning.

Furthermore, the authorized users and local stewardship associations of the NUP exist at various levels of government, from local to regional to national and even international levels (see Table 3 ). However, most operate at the local level. Of the claimants, the WWF operates at an international level and the SNF at a regional level. The locally evolved claimants are the Stockholm Bird Watching Club, a fishing association called "Patrullen Utter," and the Association of Bergshamra for All ("Bergshamra för alla"). Like these, most of the proprietors have evolved locally, and only Stockholm Water Inc. operates at the regional level. Land ownership in the NUP is overwhelmingly in the hands of the state [although there are quite a few detached houses that are privately owned in the NUP, but the local homeowners have not previously been analyzed]. 
Fig. 5. The governance system of the National Urban Park, including stewards and stewardship associations with different operational property rights

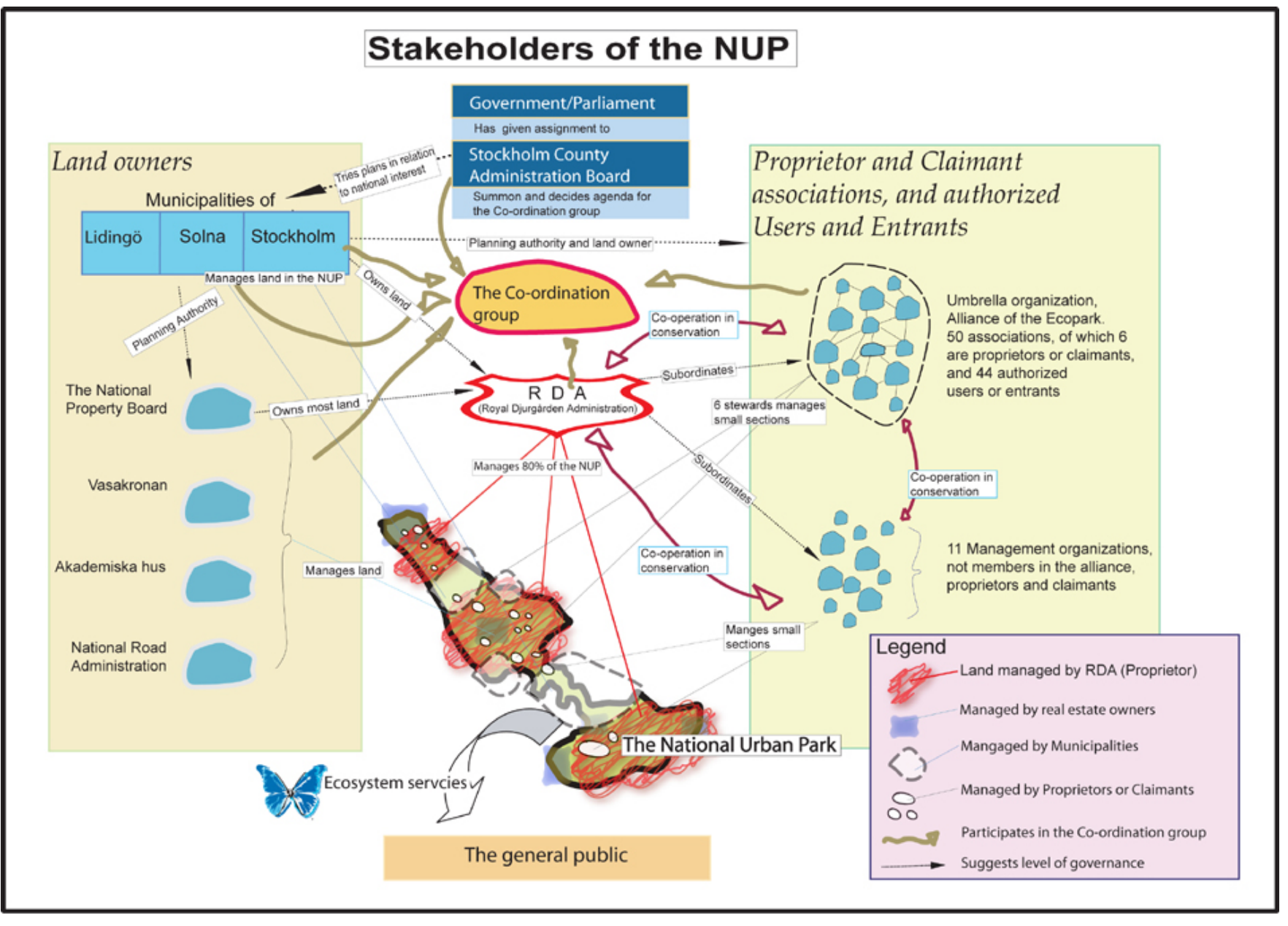

Continuous active management is crucial to sustain the biological values and associated ecosystem services in this cultural urban landscape. In Table 2 , we present the first tentative results of an analysis of the different stewards and local stewardsip associations of the park in relation to the habitats and ecosystem services (Daily et al. 1997) with which they are connected. Not surprisingly, most stewards are involved with recreational services. What is more surprising is the number of stewards who take part in managing habitats that have the potential to support seed dispersal and pollination, and to serve as genetic banks. Hence, continuing inclusion of many local stewards in the governance of the NUP may play an important role in sustaining the flow of these ecosystem services. This role of local stewardship associations has long been overlooked in resource and ecosystem management, but is increasingly appreciated and may play a central role in adaptive co-management and governance. However, there may be potential tradeoffs between different ecosystem services delivered from the NUP, because of the vast number of local stewards involved in management. One example is the trade-off between public recreational values and the support services offered by allotment gardens. Allotment gardens are fenced-off areas for horticulture that prohibit horseback riding or dog walking and some other public recreational services. On the other hand, these small-scale 
gardens provide supporting ecosystem services with cross-scale links to the larger ecosystem, such as pollination, seed dispersal, and insect pest regulation.

\section{DISCUSSION}

In our historical account, we described the development of contemporary NUP, and stated that the park's landscape and its rich biological diversity are a result of social-ecological interactions and coevolution. Given that humans have continuously exploited the area with diversified and intensified land uses with time, the park's ecosystems have been strongly influenced by societal changes. There was no pre-human period in the area-it was transformed into an agricultural landscape as soon land-upheaval processes provided human settlers with fertile fine sedimentary soils. Gradually, it was expropriated by royalty becaue of its fertile soils and proximity to Stockholm, and it became valued for its suitability as a hunting ground, and later, for its esthetic values. Throughout history, the area was managed by royal initiatives according to varying ideals. Over time, city dwellers began to benefit from the area for recreational green space. During the last 200 years, land use in the area has diversified. It seems that the period before industrialization mainly caused temporary potential crises in ecosystems in contrast to more permanent habitat destruction such as construction of city quarters and other establishments (see Fig. 4).

In areas experiencing rapid social and environmental transformations, such as Stockholm County, there is a need to develop a social capacity for urban ecosystem management to respond to change, and to develop policy directions that can help build resilience to deal with further change. Berkes et al. (2003) refer to such a capacity as "adaptive capacity." As the theories on common property systems (Ostrom and Schlager 1996, Ostrom 1998) and complex adaptive systems (Levin 1998) indicate, adaptive capacity is constrained by social institutions and the resilience of the natural systems on which they depend (Berkes et al. 2003).

A crucial part of building adaptive capacity is a governance system that can learn from experience and generate knowledge across organizational levels. Institutions and their links (both vertically and horizontally across organizational levels, and involving local people, scientists, and authorities) appear crucial in this regard because they promote information exchange to effectively deal with change and issues that transcend locality (Folke et al. 2003).

The simplest kind of cross-scale institutional link is one that connects local-level management with government-level management in partnerships, e. g., co-management (Pomeroy and Berkes 1997, Berkes et al. 2000). Co-management designs have the potential to lower overall costs of management, most notably costs incurred for describing and monitoring the ecosystem, designing regulations, coordinating users, and enforcing regulations (Hanna 1998, Johannes 1998). Also, the active involvement of citizens (through, e.g., local Agenda 21 activities) may be facilitated through comanagement designs. Thus, the potential of comanagement designs is well worth exploring for urban ecosystem management as well (Colding et al., in preparation).

Adaptive co-management has been suggested as an expansion of co-management to include adaptive management perspectives and actions as well (Olsson et al. 2004). Adaptive co-management systems are flexible systems of resource management tailored to specific places and situations and supported by, and working with, various organizations at different levels. Folke et al. (2002) define adaptive co-management as a process by which institutional arrangements and ecological knowledge are tested and revised in a dynamic, ongoing, self-organized process of learning-bydoing. The sharing of management power and responsibility may involve multiple institutional links among users, local stewardship association, government agencies, and non-governmental organizations (NGOs) (Olsson et al. 2004).

\section{The Prospects for Adaptive Co-management of the NUP}

Although an institutional analysis of this kind requires further research, nevertheless we would like to highlight some key points of this organizational web that largely serves as an analysis of some preconditions important for adaptive comanagement. Institutional theory normally assumes that ownership of land creates the strongest incentives for promoting the efficient use of property because it creates incentives for not misusing land, thus the value of the land is likely to 
increase over time. On the other hand, and as we argue here, owners may wish to sell land, and thus turn productive land into real estate. Also, owners may terminate land-lease contracts, and thus change land use. All these characteristics render owners the most influential of the local stewardship groups of the NUP. Although ownership may promote the efficient use of property, empirically conducted institutional studies suggest that it is not a necessary outcome, and that proprietors can also make decisions that promote long-term investment in and harvesting from a resource (Ostrom and Schlager 1996).

Even so, if collective-choice arenas exist, empirical studies suggest that even authorized users, such as sport-fishing associations, can influence decisions regarding management and exclusion; therefore, such arenas have the potential to create incentives for sustaining the capacity of ecosystems to generate services. Collective-choice arenas entail that most individuals affected by operational rules are included in a group that can modify these rules (Ostrom 1990). Such arenas can involve settings that are not official legislative or judicial settings (Ostrom and Schlager 1996), but can be developed through local self-organization, in which participation can promote conflict-resolution processes and provide mechanisms to back up local monitoring and sanctioning efforts.

In the case of the NUP, the Swedish Government has placed the overarching responsibility for its protection on the

Stockholm County Administrative Board, operating at the regional governance level. The board has the authority to prohibit plans that violate regulations concerning the protection of the park, and it has the responsibility to coordinate all stakeholders involved in the NUP, in what is called "the coordination group." The aim is to exchange information, settle conflicts, and develop a common management plan for the NUP. A number of stewards and conservation groups that articulate local values of the park participate in the group (see Fig. 5). However, conflicts of interest and tensions have arisen in this top-down structure, to some extent due to different perceptions and perspectives on urban development vs. conservation values of the park (Wirén 2002). Wirén (2002) also detected numerous conflicts between associations within the coordination group due to trade-offs between the interests of the various players and holistic recreational and biological values of the NUP.
Moreover, dialogue among the various proprietors and owners about practical management is currently limited (Borgström 2003). Thus, conflicts and limited dialogue are deficits that slow down crosslevel interactions among stakeholders. For instance, the key water manager, Stockholm Water Inc., is not represented in the coordination group, although water bodies and wetlands are ecologically connected to the rest of the landscape.

As the social inventory reveals, there are as many as 69 stakeholder groups directly and indirectly involved in the management of the NUP. We have found that several of these seem to be stewards of urban green habitats that generate valuable ecosystem services (Table 2). The locally selforganized user and interest groups of the NUP may be suitable candidates to participate in monitoring the effects of pilot management projects. People in these organizations have often been active in the area for decades, which presumably gives some of them experience in manageing local resources and ecosystems. Moreover, because their time spent in the locale is on a volunteer basis, monitoring is likely to be highly cost effective. There should be a potential to develop an ecosystem-based management approach to the NUP, involving those stewards in ecosystem management and restoration. It could follow an adaptive co-management approach.

As argued by Ruitenbeck and Cartier (2001), comanagement is an emergent property of resource management systems, not an arrangement that should be top-down legislated, but one that develops spontaneously. However, it needs to be framed by higher-level institutions, what Folke et al. (2003) refer to as framed creativity. Olsson et al. (2004) argue that conditions can be created to facilitate the emergence of adaptive co-management systems. These include enabling legislation that creates social space for ecosystem management, providing funds for responding to environmental feedback, facilitating information flow through social networks, combining various sources of information and knowledge, sense-making between knowledge traditions, and establishing arenas for collaborative learning of ecosystem management. These conditions reflect cross-scale dynamics of adaptive co-management and involve the roles of key individuals and trust building throughout the process.

We suggest that several of the above conditions already seem to exist in the NUP, such as 
institutional space, funding possibilities, and existence of arenas for collaborative learning. As our social inventory indicates, there are horizontal links between local stewards of the NUP, as well as vertical links between different levels of government and governance. However, information flow and a social network for building ecosystem management still need to be developed. This may require increased coordination among local stewardship associations that are active in both the NUP and other green spaces in the Stockholm metropolitan region.

\section{CONCLUSIONS}

Through our historical analysis, we have illustrated that human actions have shaped and generated the high level of biodiversity found in the NUP of Stockholm. The parks's biodiversity is a result of a cultural landscape with a long-term social memory of park management. The property rights of the area, in particular its function as royal land, have contributed to filtering short-term trends, and have prevented its transformation into an intensive production landscape. However, the rapid growth of the Stockholm metropolitan region now challenges the values of the park through urban growth and through increased isolation of the park in the broader green space landscape. In order to protect the park, legislation in 1995 gave the area status as an area of national interest. However, urban sprawl continues both inside and on the fringes of the park. A further step may be to turn the park into a nature reserve, as is currently proposed by some regional actors.

Although protected area management may be one way to go in urban areas, such an approach ignores the important aspect that active management by a considerable number of local stewards with a stake in ecosystem management has contributed to the high biodiversity levels presently existing in the park. The analysis indicates that the widespread involvement of stewardship associations may play a significant role in generating and sustaining socially valuable ecosystem services, such as recreation, seed dispersal, and pollination. Many of the local stewards manage the locales in the park on a voluntary basis, using different management practices.

The Swedish Government has given the Stockholm County Administrative Board the task of developing an overall management plan for the NUP. Adaptive co-management may be worth exploring for the management of the NUP in this context, or at least for parts of the park. The 25 identified stewardship organizations with management rights operating in the NUP seem to be suitable candidates for participation. Policy makers should create incentives for coordinating these associations horizontally and with other levels of vertical governance in the park and of surrounding green spaces, including government agencies, such as municipalities, county administration, and concerned NGOs. It may increase the likelihood of sustaining the socially valuable ecosystem services of the Stockholm urban green spaces.

Responses to this article can be read online at: http://www.ecologyandsociety.org/vollo/iss2/art10/responses/

\section{Acknowledgments:}

We thank Peter Schantz, Henrik Waldenström, and Inger-Marie Opperud at the Alliance of the Ecopark and Henrik Niklasson at KDF for sharing time and information. Thanks to Erik Andersson, Sara Borgström, Linda Wirén, and Sara Herdin for sharing their experiences and information from their field work. Thanks also to Anderas Duit at CTM and to Maria Tengö, Jakob Lundberg, and Henrik Ernstson, at the Department of Systems Ecology, for inspiring ideas and support. Thanks also to the anonymous reviewers of this paper. The Swedish Research Council Formas provided financial support for the work.

\section{LITERATURE CITED}

Andersson, E. 2003. Composition of territories and breeding success of Eurasian Jays (Garrulus glandarius) in the National City Park of Stockholm. Thesis, Department of Systems Ecology, Stockholm University, Stockholm, Sweden.

Baskin, Y. 1997. The work of nature-how the diversity of life sustains us. Island Press, Washington, D.C., USA. 
Berkes, F., J. Colding, and C. Folke. 2000. Rediscovery of traditional knowledge and resource management as adaptive management. Ecological Applications 10:1251-1262.

Berkes, F., J. Colding, and C. Folke, editors. 2003. Navigating social-ecological systems: building resilience for complexity and change. Cambridge University Press, Cambridge, UK.

Berkes, F., and C. Folke, editors. 1998. Linking social and ecological systems. Management practices and social mechanisms for building resilience. Cambridge University Press, Cambridge, UK.

Bernard, H. R. 1994. Research methods in anthropology: qualitative and quantitative approaches. Sage Publications, Newbury Park, California, USA.

Bolund, P., and S. Hunhammar. 1999. Ecosystem services in urban areas. Ecological Economics 29:293-302.

Borgström, S. 2003. Management of urban green areas in the Stockholm County. Thesis, Department of Systems Ecology, Stockholm University, Stockholm, Sweden.

Boström, M. 2001. Miljörörelsens mångfald. Dissertation, Department of Sociology (SCORE), Stockholm University, Bjärnums tryckeri, Bjärnum, Sweden.

Bratt, P., and Stockholms Läns Museum. 1998. Forntid i ny dager: Arkeologi i Stockholmstrakten. Raster förlag, Stockholm, Sweden.

Bråvander, L.-G., and R. Jakobsson. 2003. Skötselplan-Nationalstadsparken. Remissversion, November 2003, KDF, Sweden.

Brusewitz, G. 1995. Inte bara djuren på Skansen. Pages 110-123 in G. Brusewitz and H. Ekman, editors. Ekoparken-Djurgården, Haga, ulriksdal. Wahlsröm and Widstrand, Stockholm, Sweden.

Brusewitz, G., and H. Ekman, editors. 1995. Ekoparken-Djurgården, Haga, ulriksdal. Wahlsröm and Widstrand, Stockholm, Sweden.

Carpenter, S., B. Walker, J. M. Anderies, and N. Abel. 2001. From metaphor to measurement: resilience of what to what. Ecosystems 4:765-781.

Colding, J., T. Elmqvist, and P. Olsson. 2003. Building resilience in social-ecological systems. Pages 163-185 in F. Berkes, J. Colding, and C. Folke, editors. Navigating social-ecological systems: building resilience for complexity and change. Cambridge University Press, Cambridge, UK.

Colding, J., and C. Folke. 1997. The relations among threatened species, their protection and taboos. Conservation Ecology 1(6):1-19. (Online.) URL:

http://www.ecologyandsociety.org/vol1/iss1/art6/.

Collins, J. P., A. Kinzig, N. B. Grimm, W. F. Fagan, D. Hope, J. Wu, and E. T. Borer. 2000. A new urban ecology-modeling human communities as integral parts of ecosystems poses special problems for the development and testing of ecological theory. American Scientist 88:416-425.

Costanza, R., R. d'Arge, R. de Groot, S. Farber, M. Grasso, B. Hannon, S. Naeem, K. Limburg, J. Paruelo, R. V. O'Neill, R. Raskin, P. Sutton, and M. van den Belt. 1997. The value of the world's ecosystem services and natural capital. Nature 387:253-260.

Couch, C., and J. Karecha. 2003. Theories and measurement of urban sprawl and a case study of Liverpool. Pages 9-25 in I. Bergström, editor. Urban sprawl in Europe-processes, causes, measurements, consequences, policies. Lenanders gafiska AB, Karlskrona, Sweden.

Daily, G., editor. 1997. Nature services: societal dependence of natural ecosystems. Island Press, Washington, D.C., USA.

Daily, G., S. Alexander, P. Ehrlich, L. Goulder, J. Lubchenco, P. Matson, H. Mooney, S. Postel, S. Schenider, D. Tilman, and G. Woodwell. 1997. Ecosystem services: benefits supplied to human societies by natural ecosystems. Issues in Ecology 2:2-16.

Drayton, B., and R. B. Primack. 1996. Plant species lost in an isolated conservation area in metropolitan Boston from 1894 to 1993. Conservation Biology 10:30-39.

Edlund, B. 1991. Haga-Brunnsviken. New 
Interlitho SPA, Milano, Italy.

Elmqvist, T., Colding, C., Barthel, S., Diut, A., Borgström, S., Lundberg, J., Andersson, E., Ahrné, K., Erntsson, H., Folke, C., and Benktsson, J. 2004. The dynamics of socialecological systems in urban landscapesStockholm and the National Urban Park, Sweden. Annals of New York Academy of Science 1023:308322.

Fogelfors, H., and Hansson, M. 1997. Bete och våra hagmarker -flora och vegetationsutveckling. Sveriges Lantbruks Universitet. (Online.) URL: http://sll.bibul.slu.se/sok.html/.

Folke, C., Carpenter, S., Elmqvist, T., Gunderson, L., Holling, C. S., Walker, B., Bengtsson, J., Berkes, F., Colding, J., Danell, K., Falkenmark, M., Gordon, L., Kaspersson, R., Kautsky, N., Kinzig, A., Levin, S., Mäler, K-G., Moberg, M., Ohlsson, L., Olsson, P., Ostrom, E., Reid, W., Rockström, J., Svanije, H., and Svedin, U. 2002. Resilience and sustainable development: building adaptive capacity in a world of transformations. Scientific background paper on resilience for the process of The World Summit on Sustainable Development, on behalf of The Environmental Advisory Council to the Swedish Government. Edita Norsteds tryckeri AB, Stockholm, Sweden.

Folke, C., Colding, J., and Berkes, F. 2003. Building resilience and adaptive capacity in socialecological systems. Pages 352-387 in F. Berkes, J. Colding, and C. Folke, editors. Navigating socialecological systems: building resilience for complexity and change. Cambridge University Press, Cambridge, UK.

Folke, C., Holling, C. S., and Perrings, C.A. 1996. Biological diversity, ecosystems and the human scale. Ecological Applications 6:1018-1025.

Fowler, F. J. Jr. 1993. Survey research methods. Sage Publications, Beverly Hills, California, USA.

Frängsmyr, T. 1984. Paradiset och vildmarken. Studier kring synen pånaturen och naturresurserna. Liber förlag, Stockholm, Sweden.

Gothnier, M., G. Hjort, and S. Ouml;stergård. 1999. Rapport från Artarken. Stockholms artdataarkiv. Miljöförvaltningen, Stockholm. (Stockholm
Environmental and Health Protection Administration.)

Grimm, N. B., J. M. Grove, S. T. A. Picket, and C. L. Redman. 2000. Integrated approaches to long-term studies of urban ecological systems. Bioscience 50(7):571-583.

Gustavsson, P. 1998. De äldsta spåren efter människor. Pages 23-31 in P. Bratt and Stockholms läns museum, editors. Forntid i ny dager: Arkeologi I Stockholmstrakten. Raster förlag, Stockholm, Sweden.

Hanna, S. S. 1998. Managing for human and ecological context in the Maine soft shell clam fishery. Pages 190-211 in F. Berkes and C. Folke, editors. Linking social and ecological systems. management practices and social mechanisms for building resilience. Cambridge University Press, Cambridge, UK.

Herdin, C. 2002. Nationalstadsparkens ekpopulationer -skötsel och förvaltning frän 1600-talet till nutid. Examination paper 2002:12. Department of Systems Ecology, University of Stockholm, Sweden.

Holm, L., and P. Schantz, editors. 2002. Nationalstadsparken-ett experiment $i$ hållbar utveckling. Fält and Hässler, Värnamo, Sweden.

Hultgren, S., H. Peijel, and M. Holmer. 1997. Ekjättar. Naturcentrum, Stenungssund, Sweden.

Johannes, R. 1998. The case for data-less marine resource management: examples from tropical nearshore fin fisheries. Trends in Ecology and Evolution 13(6):253-256.

Johanisson, K. 1984. Det sköna i det vilda. Pages 3-25 in T. Frängsmyr, editor. Paradiset och vildmarken. Studier kring synen på naturen och naturresurserna. Liber förlag, Stockholm, Sweden.

Kinzig, A. P. 2001. Bridging disciplinary divides to address environmental and intellectual challenges. Ecosystems 4:709-715.

Kvale, S. 1996. Interviews: an introduction to qualitative research interviewing. Sage Publications, Thousand Oaks, California, USA.

Lange, U. 2000. Exprimentfältet-Kungliga Lantbruksakademins experiment och försöksverksamhet 
på norra djurgården $i$ Stockholm 1816-1907. Uppsala, Sweden.

Levin, A. S. 1998. Ecosystems and the biosphere as complex adaptive systems. Ecosystems 1:431-436.

Lignell, C. 1995. Ur Kungliga djurgårdens historia. Pages 28-47 in Sankt Eriks Arsbok. National Stads Parken. Almqvist and Wiksell tryckeri AB, Uppsala, Sweden.

Lindhagen, A. 1916. Koloniträdgårdar och planterade gårdar. Rekolid. Stockholm, Sweden.

Loberg, B. 1993. Geologi. Material, processer, och Sveriges berggrund. Norstedts, Borås, Sweden.

Löfvenhaft, K. 2002a. Biodiversity in urban areas - examples from the National Urban Park. Pages 31-49 in P. Schantz and L. Holm, editors. The National Urban Park-an experiment in sustainable development. Fälth and Hässler, Värnamo, Sweden.

Löfvenhaft, K. 2002b. Spatial and temporal perspectives on biodiversity for physical planning - examples from urban Stockholm, Sweden. Dissertation, Department of Physical Geography, Stockholm University, Katarina Tryck, Stockholm, Sweden.

Löfvenhaft, C., and Lannek, J. 2002. Biotope map of Stockholm. Älvsby Tryck, Älvsby. Sweden.

Lundberg, J., E. Andersson, G. Cleary, and T. Elmqvist. Submitted. Mobile links and processoriented management: maintaining functions in fragmented ecosystems. Conservation Biology.

Lundevall, P. 1997. Djurgården Kungens och folkets park. Stadsbyggnadskontoret, Västervik, Sweden.

Lundh, E. 1928. Festskrift-utgiven med anledning till Skogshögskolans 100-års jubileum 1829-1928. Pages 1-30 in T. Lagerberg, editor. Centraltryckeriet Stockholm, Stockholm, Sweden.

Lundqvist, L. 1971. Miljövärdsförvaltning och politisk struktur. Berlinska Boktryckeriet, Lund, Sweden.

Nabhan, G. P., and S. L. Buchman. 1997. Services provided by pollinators. Pages 133-150 in G. Daily, editor. Nature services: societal dependence of natural ecosystems. Island Press, Washington, D. C., USA.

Naylor, R. L., and P. Ehrlich. 1997. Natural pest control services and agriculture. Pages 151-174 in G. Daily, editor. Nature services: societal dependence of natural ecosystems. Island Press, Washington, D.C., USA.

Niemi, G., J. Hanowskil, and P. Helle. 1998. Ecological sustainability of birds in boreal forests. Conservation Ecology 2(2): 1-17.

Nilsson, L. 2000. En historiskt hållbar stad. Pages ?-? in M. Bertilssdotter, K. Jegerfors, and F. Snickars, editors. Det framtida Stockholm-Den högteknologiska stadens resurser. AiT Scandbook, Falun, Sweden.

Nolin, C. 2003. Koloniträdgårdsrörelsen i Stockholm-dess förutsättningar och uppkomst vid 1900-talets början. Pages 9-40 in C. Westergren, editor. Stades Odlare. Nordiska Museets förlag, Stockholm, Sweden.

Norrby, E. 2002. National stadsparkens många ansikten. In Kungliga vetenskaps akademin \& Nationalstadsparken. Stockholm, Sweden.

Olsson, P., C. Folke, and F. Berkes. 2004. Adaptive comanagement for building resilience in socialecological systems. Environmental Management 34 (1):75-90.

Ostrom, E. 1990. Governing the commons: the evolution of institutions for collective action. Cambridge University Press, Cambridge, UK.

Ostrom, E. 1998. A behavioral approach to the rational choice theory of collective action. American Political Science Review 92(1):1-22.

Ostrom, E., and E. Schlager. 1996. The formation of property rights. Pages 127-157 in S. Hanna, C. Folke, and K.-G. Mäler, editors. Rights to Nature. Island Press, Washington, D.C., USA.

Patton, M. Q. 1980. Qualitative evaluation methods. Sage Publications, Beverly Hills, California, USA.

Peters, D. B. C., and S. Goslee. 2000. Landscape diversity. Pages 645-658 in S. A. Levin, editor. Encyclopedia of biodiversity, volume 3. Academic 
Press, San Diego, California, USA.

Pickett, S. T. A., M. L. Cadenasso, J. M. Grove, C. H. Nilon, R. V. Pouyat, W. C. Ziperer, and R. Costanza. 2001. Urban ecological systems: linking terrestrial, ecological, physical and socioeconomic components of metropolitan areas. Annual Review of Ecological Systems 32:127-57.

Pomeroy, R. S., and F. Berkes. 1997. Two to tango: the role of government in fisheries co-management. Marine Policy 21(5):465-480.

Ranius, T., K. Antonsson, N. Jansson, and J. Johanneson. 2001. Inventering och skötsel av gamla ekar $i$ eklandskapet söder om Linköping. Fauna och Flora, Linköping, Sweden.

Recher, H. F., and D. L. Serventy. 1991. Long term changes in the relative abundance of birds in Kings Park, Perth. Conservation Biology 5:90-102.

Rubenson, S. 2000. Miljöbalken. Norstedts, Stockholm, Sweden.

Ruitenbeck, J., and C. Cartier. 2001. The invisible wand: adaptive co-management as an emergent strategy in complex bio-economic systems. Occasional paper 34. Center for International Forestry Research, Bogor, Indonesia.

Schantz, P. 2002. Det historiska landskapets kulturvärden. Pages 99-113 in P. Schantz and L. Holm, editors. Nationalstadsparken-ett experiment $i$ hållbar utveckling. Fält and Hässler, Värnamo, Sweden.

Schultz, L., P. Olsson, Å. Johannessen, and C. Folke. 2004. Ecosystem management by local steward associations. A case study from "Kristianstads vattenrike," the Swedish MA. Conference paper in Bridging scales and epistemologies: linking local knowledge and global science in multi-scale assessments (Alexandria, Egypt, 2004).

Sjöberg, F. 2002. Naturens nollåttor. Miljöförvaltningen, Stockholm, Sweden.

Slottsarkivet E1:5. 1807. Memorial ställd av Israel av Ström den 26 mars 1807. Skrivelse till överhovjägmästare ämbetet. Djurgårdsförvaltningen, E1:5 1718-1805.
Stockholm County Administration Board. (Länstyrelsen i Stockholms Län.) 1999.

Nationalstadsparken-mål och riktlinjer för skötsel av park och natur. Miljö- och planeringsavdelningen nr 18. (Online.) URL: www.ab.lst.se.

Stockholm Environmental and Health Administration. (Miljöförvaltningen, Stockholms stad.) 1994. Vattenprogram för Stockholm-sjöar och vattendrag. Miljöförvaltningen, Stockholm, Sweden.

Stockholm Planning Administration. (Stockholms stadsbyggnadskontor, Strategiska avdelningen.) 1997. Nationalstadsparkens ekologiska infrastruktur. Stadsbyggnadskontoret, Stockholm, Sweden.

Stockholm Planning Administration. (Stockholms stadsbyggnadskontor, Strategiska avdelningen.) 1998. Natur \& kulturmark i Nationalstadsparken. Brunnsviken-Haga-brunnsviken-Djurgården. Stockholms stadsbyggnadskontor, Stockholm, Sweden.

Swedish Government. 2002. En samlad naturvårdspolitik. (A unified nature management policy.) Regeringens skrivelse 2001/02:173. (Online.) URL: http://www.sweden.gov.se/.

van Rooijen, M. 2004. A walk in the park as a democratic right. European Urban History Conference (Athens, Greece, 2004).

Waldenström, H. 1995. Ekoparken blir nationalstadspark. Kampen om Ulirksdal-Haga-Brunnsviken-djurgården. Pages 157-171 in Sankt Eriks årsbok. Nationalstadsparken. Almqvist and Wiksell tryckeri AB, Uppsala, Sweden.

Wirén, L. 2002. Dynamik i urbana nätverk-sociala och ekologiska perspektiv på förvaltningen av Nationalstadsparken $i$ Stockholm. Examination paper 2002:10. Department of Systems Ecology, University of Stockholm, Sweden. 
APPENDIX 1. A list of websites and maps consulted for the purposes of this research, and details on interviews with stakeholders in the NUP

Websites

Alliance of the Ecopark: http://www.ekoparken.org/

Garden of Rosendal (Rosendals Trädgård). Home page, 2003-11-25: http://www.rosendalstradgard.com/

Millennium Ecosystem Assessment (MA): www.millenniumassessment.org/

Royal Djurgården Administration (in Swedish, "Kungliga Djurgårdsförvaltningen”:

http://www.djurgardskartor.lantmateriet.se/

Stockholm Urban Assessment (SUA-Sweden): $\underline{\text { www.ctm.su.se/SummaryofStockholmUr/ }}$

Stockholm County Administration Board: $\underline{w w w . a b . l s t . s e}$

Stockholm University, Center for Transdisciplinary Environmental Research: Homepage, 2004-11-20. www.ctm.su.se/SummaryofStockholmUr/

Stockholm University, Department of History. Illstration of population dynamics of the city, 2003-11-07: http://www.historia.su.se/urbanhistory/cybcity/sthlm/befolk.htm

Swedish Allotment Union. Homepage, 2003-11-07: http://www.koloni.org/pdf/01.pdf

Maps

Löfvenhaft, C., and Lannek, J. 2002. Biotope map of Stockholm. Älvsby Tryck, Älvsby, Sweden.

Stockholms stadsbyggnadskontor. 1998. Natur \& kulturmark i Nationalstadsparken. Brunnsviken-Hagabrunnsviken-Djurgården. Stockholms stadsbyggnadskontor, Stockholm, Sweden.

Interviews

Opperud, I. M. Chairwoman of the allotment association of Söderbrunn and member of Alliance of the Ecopark. 2003-05-28.

Schantz, P. Vice chairman of Haga-Brunnsvikens vänner and board member of Alliance of the Ecopark. 2003-03-22.

Waldenström, H. Member of the board of the Alliance of the Ecopark, part time employe of WWF and member of Stockholms Ornitologiska förening. 2003-04-09. 
APPENDIX 2. Organizations and associations that are linked to the National Urban Park

\begin{tabular}{lccc}
\hline \hline Management Organization & Main Aim of Activity & Management Locale \& Objective & $\begin{array}{l}\text { Associatd } \\
\text { Property R- } \\
\text { ight }\end{array}$ \\
\hline
\end{tabular}

\section{Global Level}

World Wildlife Foundation

\section{National Level}

National Property Board

Swedish National Road Administration

Vasakronan

Municipality of Stockholm

Municipality of Solna

Municipality of Lidingö

Akademiska hus

\section{Regional Level}

The Swedish Society for Nature Conservation, Stockholm County (SNF)

Stockholm Water Inc.

\section{Local Level}

Royal Djurgården Administration (KDF)

Botanic Garden of Bergius

Maintenance of culture and biodiversity

Maintenance of culture and biodiversity

Maintenance of culture and biodiversity

Real estate owner

Maintenance of biodiversity

Decrease eutrofication and pollution

Demonstrate biodiversity

Education/recreation

The 4H Farm of Stora skuggan
Restoration of the wetland of Fisksjöäng \& high Claimant land cattle project
Owner

Maintenance of the Royal palaces and parks
Ulriksdal, Rosendal, and Haga, as well as the

Islets of Skeppsholmen and Kastellholmen.

Roads and highways in the park Owner

Management of Sörentorp, park management Owner

Maintenance of Bellevue, the Royal Institute of Owner Technology and the City quarters of Gärdet and Ekhagen

Maintenance of Tivoli, Haga södra, Frösundavik, Owner and the city quarter of Bergshamra

Maintenance of the islets of Fjäderholmarna

Owner

Management of the green space around "the Science City." Clearing of land and park

Owner management

Haymaking, oak planting, maintenance of ponds

Claimant and nesting boxes in the park

Restoration and maintenance of wetlands and water bodies

Proprietor

Maintenance of about $80 \%$ of NUP

Proprietor

Gardening and bee keeping

Proprietor

Gardening, grazing, and bee keeping

Proprietor 
Patrullen Utter

Outdoor museum of Skansen

Allotment area of Söderbrunn

Allotment area of Kvarnvreten

Allotment area of Frescati

Allotment area of Jakobsdal

Bergshamra för alla

Allotment area of Bergshamra

Garden of Rosendal

Stockholms Ornitologiska förening

Allotment area of Stora

Skuggan

Cemetery of Ulriksdal, Solna

Kyrka

\section{User Organization}

\section{National Level}

Friskis och svettis

Fältbiologerna

$\underline{\text { Svenska Cykelsällskapet }}$
Sport fishing

Education/recreation

Cultivation/recreation

Cultivation/recreation

Cultivation/recreation

Cultivation/recreation

Maintenance of culture and biodiversity

Cultivation/recreation

Biodynamic cultivation

Recreation/bird watching

Cultivation/recreation

Burials

Recreation and sport N/A

Biodiversity conservation N/A

N/A

Recreation/biking
Claimant

Maintenance of the miniature cultural landscapes Proprietor of Sweden, gardening and park management

Gardening

Proprietor

Gardening

Proprietor

Gardening

Proprietor

Gardening

Proprietor

Haymaking and tree cutting at Tivoli

Claimant

Gardening and maintenance of the commons

Proprietor

Gardening, park management, and organic cultivation

Proprietor

Restoration and maintenance of nesting boxes and bird habitats

Claimant

Gardening

Proprietor

Lime-tree planting, haymaking, nesting boxes for small birds

Proprietor
Authorized user

Authorized user

Authorized entrant

\section{Regional Level}

Friluftsfrämjandet, stockholm

Outdoor sport

N/A

Authorized entrant

Saltsjöbadens Naturskyddsförening Biodiversity conservation N/A

Authorized entrant

\section{Local Level}

Albano Båtklubb

Recreation/boating

N/A

Authorized user 


\begin{tabular}{|c|c|c|c|}
\hline Föreningen äventyrarna & Recreation/adventure & N/A & $\begin{array}{l}\text { Authorized } \\
\text { entrant }\end{array}$ \\
\hline $\begin{array}{l}\text { Stockholms Orienteringsf- } \\
\text { örbund }\end{array}$ & Orienteering & N/A & $\begin{array}{l}\text { Authorized } \\
\text { user }\end{array}$ \\
\hline $\begin{array}{l}\text { Svenska Turistföreningen } \\
\text { Stockholmskretsen }\end{array}$ & Lobbying & N/A & $\begin{array}{l}\text { Authorized } \\
\text { entrant }\end{array}$ \\
\hline $\begin{array}{l}\text { Djurgårdens -Lilla Värtans } \\
\text { miljöskyddsförening }\end{array}$ & Lobbying & N/A & $\begin{array}{l}\text { Authorized } \\
\text { user }\end{array}$ \\
\hline Djurgårdens Hembygdsförening & Culture conservation & N/A & $\begin{array}{l}\text { Authorized } \\
\text { user }\end{array}$ \\
\hline Haga brunnsvikens vänner & Lobbying & N/A & $\begin{array}{l}\text { Authorized } \\
\text { user }\end{array}$ \\
\hline Haga Båtklubb & Recreation/boating & N/A & $\begin{array}{l}\text { Authorized } \\
\text { user }\end{array}$ \\
\hline Segelsällskapet Brunnsviken & Recreation/boating & N/A & $\begin{array}{l}\text { Authorized } \\
\text { user }\end{array}$ \\
\hline Segelsällskapet vega & Recreation/boating & N/A & $\begin{array}{l}\text { Authorized } \\
\text { user }\end{array}$ \\
\hline Stallmästaregårdens båtsällskap & Recreation/boating & N/A & $\begin{array}{l}\text { Authorized } \\
\text { user }\end{array}$ \\
\hline Mellan Järva stallet, 851562 & Horseback riding & N/A & $\begin{array}{l}\text { Authorized } \\
\text { user }\end{array}$ \\
\hline Ulriksdals hembygdsförening & Lobbying & N/A & $\begin{array}{l}\text { Authorized } \\
\text { user }\end{array}$ \\
\hline Symbios & Lobbying & N/A & $\begin{array}{l}\text { Authorized } \\
\text { entrant }\end{array}$ \\
\hline $\begin{array}{l}\text { Kommittén Gustavianska } \\
\text { parken }\end{array}$ & Lobbying & N/A & $\begin{array}{l}\text { Authorized } \\
\text { user }\end{array}$ \\
\hline Samfundet St Erik & Lobbying & N/A & $\begin{array}{l}\text { Authorized } \\
\text { user }\end{array}$ \\
\hline $\begin{array}{l}\text { Hembygdsföreningen å } \\
\text { Norrmalm }\end{array}$ & Culture conservation & N/A & $\begin{array}{l}\text { Authorized } \\
\text { user }\end{array}$ \\
\hline Hembygdsföreningen östermalm & Culture conservation & N/A & $\begin{array}{l}\text { Authorized } \\
\text { user }\end{array}$ \\
\hline $\begin{array}{l}\text { Hyresgärstföreningen Norrmal- } \\
\text { msavdelningen }\end{array}$ & Lobbying & N/A & $\begin{array}{l}\text { Authorized } \\
\text { entrant }\end{array}$ \\
\hline $\begin{array}{l}\text { Naturskydds föreningen } \\
\text { Sollentuna }\end{array}$ & Biodiversity conservation & N/A & $\begin{array}{l}\text { Authorized } \\
\text { entrant }\end{array}$ \\
\hline $\begin{array}{l}\text { Naturskydds föreningen i solna } \\
\text { sundbyberg }\end{array}$ & Biodiversity conservation & N/A & $\begin{array}{l}\text { Authorized } \\
\text { entrant }\end{array}$ \\
\hline
\end{tabular}




\begin{tabular}{|c|c|c|c|}
\hline Norra Djurgårdens vänner & Lobbying & N/A & $\begin{array}{l}\text { Authorized } \\
\text { user }\end{array}$ \\
\hline $\begin{array}{l}\text { Norra järva } \\
\text { hembyggdsförening }\end{array}$ & Culture conservation & N/A & $\begin{array}{l}\text { Authorized } \\
\text { user }\end{array}$ \\
\hline Picknick-klubben & Recreation & N/A & $\begin{array}{l}\text { Authorized } \\
\text { entrant }\end{array}$ \\
\hline Föreningen ekhagen & Lobbying & N/A & $\begin{array}{l}\text { Authorized } \\
\text { user }\end{array}$ \\
\hline Bellevueförbundet & Lobbying & N/A & $\begin{array}{l}\text { Authorized } \\
\text { user }\end{array}$ \\
\hline Bergianska trädgårdens vänner & $\begin{array}{l}\text { Economical support to the } \\
\text { botanical garden and to } \\
\text { FFE }\end{array}$ & N/A & $\begin{array}{l}\text { Authorized } \\
\text { user }\end{array}$ \\
\hline $\begin{array}{l}\text { Kommiten för Gustavianska } \\
\text { parken }\end{array}$ & Lobbying & N/A & $\begin{array}{l}\text { Authorized } \\
\text { user }\end{array}$ \\
\hline University of Stockholm & Education & N/A & $\begin{array}{l}\text { Authorized } \\
\text { user }\end{array}$ \\
\hline Stockholms fältridklubb & Horseback riding & N/A & $\begin{array}{l}\text { Authorized } \\
\text { user }\end{array}$ \\
\hline Friluftsfrämjandet, Norra järva & Outdoor sport & N/A & $\begin{array}{l}\text { Authorized } \\
\text { entrant }\end{array}$ \\
\hline $\begin{array}{l}\text { Föreningen stockholms } \\
\text { auktoriserade guider }\end{array}$ & Guiding & N/A & $\begin{array}{l}\text { Authorized } \\
\text { entrant }\end{array}$ \\
\hline Stockholm marathon & Recreation/running & N/A & $\begin{array}{l}\text { Authorized } \\
\text { user }\end{array}$ \\
\hline Stockholms Vandrarförening & Recreation/trekking & N/A & $\begin{array}{l}\text { Authorized } \\
\text { entrant }\end{array}$ \\
\hline Föreningen natur och samhälle & Biodiversity conservation & N/A & $\begin{array}{l}\text { Authorized } \\
\text { entrant }\end{array}$ \\
\hline Södermalmsparkernas vänner & Lobbying & N/A & $\begin{array}{l}\text { Authorized } \\
\text { entrant }\end{array}$ \\
\hline Vårt Stockholm & Lobbying & N/A & $\begin{array}{l}\text { Authorized } \\
\text { entrant }\end{array}$ \\
\hline Sofia Hembygdsförening & Culture conservation & N/A & $\begin{array}{l}\text { Authorized } \\
\text { entrant }\end{array}$ \\
\hline $\begin{array}{l}\text { Svenska Turistföreningen } \\
\underline{\text { Stockholmskretsen }}\end{array}$ & Lobbying & N/A & $\begin{array}{l}\text { Authorized } \\
\text { entrant }\end{array}$ \\
\hline
\end{tabular}

